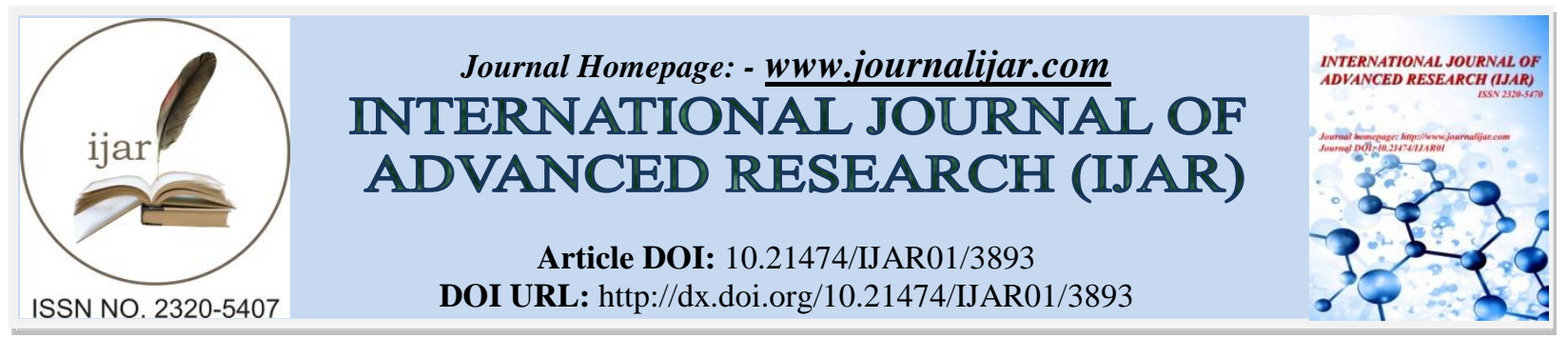

RESEARCH ARTICLE

\title{
CRITICAL THINKING: IMPERATIVE IN INFORMATION BASED SOCIETY.
}

1. Research Scholar, University of Allahabad.

2. Supervisor and Ex-Head, Department of Education, University of Allahabad.

\section{Manuscript Info}

Manuscript History

Received: 09 February 2017

Final Accepted: 10 March 2017

Published: April 2017

Key words:-

Critical thinking, Information based society

\begin{abstract}
Humans are social beings and regarded as the primates for social qualities. Society precedes the individual by making adept at utilizing communication system for self-expression. It has been thought that the power of the societies is the result of different sources. One of them is information. Presently our society is the information based society where education is perceived as learning of the life style on individual, organizational and social bases. Now information becomes a strategic resource. Today, the basic principles of life are changed and learning is redefined as strategy to manage the future and to build new ideas which make the difference in social, organizational and individual life. In fact, information based society requires critical thinking in its individuals. Thus the paper attempts to provide a rationale for the role of Critical thinking as an imperative aspect in information based society. This study represents how Critical thinking is imperative in information based society where information is in bulk from all the directions and every person is exposed but they have to know which information is to accept or reject and how to convert information into knowledge. Further the significance of teaching practices to initiate the decision making abilities on part of the individual is also discussed.
\end{abstract}

Copy Right, IJAR, 2017,. All rights reserved.

The illiterate of the 21st Century are not those who cannot read and write but those who cannot learn, unlearn and relearn."

-- Alvin Toffler, The Third Wave

\section{Critical Thinking: A Conceptual Analysis:-}

Critical thinking has been the subject of much debate and thought since the time of early Greek philosophers such as Plato, Socrates and has continued to be a subject of discussion into the modern age. Critical thinking means making reasoned judgments that are logical and well thought out. It is a way of thinking in which the individuals do not simply accept all arguments and conclusions they are exposed to. Even critical thinking involves attitude of an individual to question such arguments and conclusions. It requires a person's ability to see what evidence is involved to support a particular argument or conclusion. Now the question arises what is Critical thinking?

Corresponding Author:- Ms. Kuldeep Kaur.

Address:- Research Scholar, University of Allahabad. 
Critical thinking is the ability to think clearly and rationally by understanding the logical connection between ideas. It is the intellectually disciplined process of actively and skillfully conceptualizing, applying, analyzing, synthesizing and evaluating information gathered from different sources. This is the ability to engage in reflective and independent thinking. In essence, critical thinking requires an individual to use his ability to reason. It is about being an active learner rather than a passive recipient of information. Critical thinkers rigorously question ideas and assumptions rather than accepting them at face value. They always seek to determine whether the ideas, arguments and findings represent the entire picture. Critical thinkers identify, analyse and solve problems systematically rather than by intuition or instinct. This involves thinking about things in certain ways so as to arrive at the best possible solution in the circumstances that the thinker is aware of. In other words, it is a way of thinking about whatever is presently occupying our mind so that we can come to the best possible conclusion. It is the ability to think clearly and rationally about what to do or what to believe. With critical thinking skills an individual is able to understand the logical connections between ideas to identify and evaluate arguments. It detects inconsistencies and common mistakes in reasoning which helps to solve day to day problems systematically. Finally it reflects the justification of one's own beliefs and values.

Critical thinking includes two components. First component is a set of information and belief generating and processing skills whereas the second is habit based on intellectual commitment of using those skills to guide behavior. Critical thinking is considered important for human rights education for toleration. The Declaration of Principles on Tolerance adopted by UNESCO in 1995 affirms that Education for tolerance could aim at countering factors that lead to fear and exclusion of others and could help young people to develop capacities for independent judgement, critical thinking and ethical reasoning. Critical thinking is used as a way of deciding whether a claim is true, partially true or false. It is a tool by which one can come about reasoned conclusions based on a reasoned process.

Critical thinking can conceptualize as an attitude based on foreseeing and solving problems. This is the capacity of deduction and reasoning for being able to put all these methods into practice in daily life (Glaser, 1985). Though one possesses the skill and knowledge concerning critical thinking, one may not be able to perform better if his or her attitudes are not supported by critical thinking. Critical thinking does not only focus on "The way of thinking", but also "what factors matter in order to improve oneself" (Paul, 1996). Critical thinking is an active and organized cognitive process which enables us to be conscious of our own thinking processes to take into consideration others thoughts to practice what we have learned and understand ourselves as well as surrounding (Cüceloglu, 1994).

In the light of above approaches, Critical thinking can be defined as an ability of making effective decisions, solving problems, observing our own thoughts and a process which is based on research, intuition, logic, experience and universal values.

American Philosophical Association of critical thinking has defined critical thinking as "The process of purposeful, self-regulatory judgement. The process gives reasoned consideration to evidence, contexts, conceptualizations, methods and criteria." It emerges as a complex and comprehensive process that require a higher order of cognitive skills. Critical thinking is a factor which enables individuals to lead a more productive and independent life (Munzur, 1999).

In context of the above definitions, the experts consensus critical thinking to be purposeful, self-regulatory judgment which results in interpretation, analysis, evaluation to draw inference. Critical thinking is an essential tool of inquiry liberating force in education and a powerful resource in one's personal and civic life. It is a pervasive and selfrectifying human phenomenon. The ideal critical thinker is habitually inquisitive, well-informed, trustful of reason, open-minded, flexible, fair-minded in evaluation Thus, educating good critical thinker means working towards this ideal. It includes developing critical thinking skills with nurturing those dispositions which consistently yield useful insights and are the basis of a rational and democratic society.

A person with a good memory and who knows a lot of facts is not necessarily good at critical thinking. A critical thinker is able to deduce consequences from what he knows. He is able to make use of information acquired to solve problems. He also seeks relevant sources of information to be acquainted. Critical thinking does not only accumulate information but plays an important role in cooperative reasoning and constructive tasks. It can help us to acquire knowledge, improve our theories and strengthen arguments. We can use critical thinking to enhance work processes and to improve the performance of social institutions. 
Everyone thinks; it is our nature to do so. But much of our thinking left is biased, distorted, partial, uninformed and prejudiced. The quality of our life depends precisely on the quality of our thought. Shoddy thinking is costly, both in money and in quality of life. Excellence in thought however must be systematically cultivated. Critical thinking means making clear, reasoned judgments. During the process of critical thinking, ideas should be reasoned, well thought out and judged." (Barry K. Beyer, 1995)

Responding effectively to social and economic challenges requires people to be creative, innovative, enterprising and adaptable with the confidence to use critical thinking purposefully. The proper application of thinking skills enables people to develop sophisticated understanding of the processes they can employ for building a capacity to manage their thinking. The productive and intentional thinking is the centre of effective learning. The practice of using thinking strategies fosters the motivation for management of own learning. The aim of critical thinking capability is to ensure that individuals develop the understanding of thinking processes to apply these intentionally. Further it develops confidence in evaluating thinking processes.

\section{Critical thinking: Why is it important?}

The ability to think clearly and rationally is important whatever we choose to do. Critical thinking skills are not restricted to a particular subject area. Being able to think well and solve problems systematically is an asset for any career. Critical thinking is very important in the new knowledge economy. The global knowledge economy is driven by information and technology. One has to be able to deal with changes quickly and effectively. The new economy places increasing demands on flexible intellectual skills and the ability to analyze information and integrate diverse sources of knowledge in solving problems. Good critical thinking promotes such thinking skills and is very important in the fast-changing workplace. On the other hand, such thinking enhances language and presentation skills. People can think clearly and systematically to improve the expression of ideas. Comprehension abilities can also improve by critical thinking. It promotes creativity. The creative solution to a problem involves new ideas being generated and relevant to the task. Critical thinking plays a crucial role in evaluating new ideas, selecting the best ones and modifying them if necessary. Critical thinking is crucial for self-reflection. Critical thinking is an important element of all professional fields and academic disciplines. It is considered important in the academic fields because it enables one to analyze, evaluate, explain and restructure their thinking, thereby decreasing the risk of adopting, acting on, or thinking with, a false belief.

We need to justify and reflect on our values and decisions to live a meaningful life and to structure our lives accordingly. It acts as the tools for the process of self-evaluation. Good critical thinking is the foundation of science and democracy. Each subject requires the critical use of reason. The liberal democracy requires citizens who can think critically about social issues to inform their judgments about proper governance and to overcome biases and prejudice.

\section{Critical Thinking: Imperative in Information based society:-}

At present our society has become information based society. The technological changes since the eighteenth century have occurred so rapidly that many people are experiencing undue stress and confusion because of their inability to adapt quickly to the strategic change. (Future Shock, Toffler). The term 'Information based society' stands for a society which considers creation, distribution and manipulation of information as the most significant economic and cultural activity. Such society is characterized by the globalization of information and communication technologies. Information is the chief driver to spur the growth and development of each individual. There is flood of information gathered from various sources. The information is generated by observation, experience, reflection, reasoning and communication. Today, information acts as a guide to belief an action of an individual in the society. Sometimes bulk of information is creating confusion and chaos in the society. Since the responsibility goes to education for developing critical thinking skills among individuals so that they can avail the ability to choose right information. It helps to make effective decisions to solve day to day problems by observing their own thought processes. This ability can only be generated when the education tends toward the development of critical thinking among individuals from the early stage of learning. In the process of education, adolescence period is the most critical period when a child is susceptible to expose the turbulence of emotional and moral thought processes. Today, the students are badly exposed to IT, social media and multiple informations coming from various media and technological sources. They are notable to decode the information and they become confused, restless and 
sometimes become irrational and anti-social. It is needless to say that our society is facing the emergent problems of language, caste, creed and community.

We have the access to use the ICT infrastructure for the realization of collective and individual goals in an effective manner. The capacity to gather and share any information denotes the social and technological development. Our societal era is supported by flux and flow of information. Our economic growth is based on information and knowledge. In essence, the ability to decode information into knowledge decides our success. At present, information is the key resource for societal transformation. Due to rapid improvements in communication technologies, the primary objective for the socialization of individuals is to improve their power of decision making. The transmission of information becomes the fundamental source of productivity and power (Castells, 2000). In the new society of knowledge, access to information plays a central role on economic, social and individual basis (Bell, 1987). This is the society in which information is regarded as essential means for increasing economic productivity.

For creating better life capabilities and higher standards of living there is an extensive use of information technologies. According to the European Union, information society creates new opportunities for citizen participation by promoting the expression of opinions and views. The ability to think and evaluate the right information is used to improve the human condition. The capacity to gather and analyze information has existed throughout human history. However, the idea of the present day knowledge society is based on the vast increase in information. The UNESCO World Report addresses the definition, content and future of information based societies. The teaching of critical thinking is important for this informative era. To live a successful life people must be able to think critically in order to make sound decisions about personal and civic affairs (Beyer, 1995).

Critical thinking is often cited as one of the most meaningful learning outcomes in many information literacy plans and activities and is listed among the information competency standards. The concept of critical thinking is often related to the idea of lifelong learning. This is one of the vital competencies required to live in information based society. Critical thinking is flexible learning in an information based society. The meta-cognitive ability is a fundamental aspect of critical thinking which brings to reflect on the thinking itself. It helps to evaluate one's own thinking practice by learning from the experience. Information literacy is one of the most effective learning activities to promote critical thinking. The development of a critical attitude is stimulated by the need to identify the suitable sources followed by evaluation and synthesis of findings. Such skills emphasize learners to reflect on their own learning style to feel responsible of their thought process and to acquire control on it. Critical thinking is tremendously important to perceive the situations for making the balanced judgement. It enables to look the information appropriately so as to reach the final decision. Critical thinking is important in today's society because it gives individuals the ability to build knowledge without prior guidance. Individuals who are able to think well and solve problems systematically have an asset that is valuable for any career as well as survival in society. In the present scenario, thinking critically is very important because it provides one with a method to analyze when dealing with information. Critical thinking enables one to gather an abundance of information and allows to sum up information in a way that make. In today's society, one needs to be able to retain and respond to information given to them as efficiently as possible.

\section{Conclusion:-}

Although the rising tide of affluence has given today's youth the advantages of technology and a range of opportunities. Yet youth of modern time are mislead by the various information. It creates chaos among them to choose the right information.

The ability to think critically is not limited to the acquisition of technical and procedural knowledge. It enhances cognitive, emotive and social competences to building knowledge with full awareness in the form of communication. To have a better understanding of the initial information and content critical thinking plays a vital role. There is the need to reveal about what critical thinking is in fact and how it can be integrated with information technologies. There should be an intentional effort to go beyond the technological methods and to fully grasp critical thinking skills. We can accept that to think critically is not an innate and intuitive ability. It emerges from the teaching-learning process, being gradually and deliberately acquired. Though some reviews showed in the initial stage of education student factors, personal factors, education and child-rearing factors are the main cause to lack the power of decision making. Education factors comprised teaching methods, education media and education atmosphere. There is positive relationship between critical thinking tendencies and the factors affecting the critical thinking tendencies (Ramazan Arslan, 2014). 
The teaching method has the greatest influence on critical thinking skills. In this sense, the teacher should be aware of the student's beliefs regarding their skills, analyze how their thinking takes form and support them to unravel and correct their thinking inaccuracies.

\section{"Education is what makes a person, it is not information that stuffed into your mind, but it is something that enables you to develop and grow for the rest of your life."}

\section{- Swami Vivekananda}

\section{Reference:-}

1. Bawden, D. and L. Robinson (2002), Promoting literacy in a digital age: approaches to training for information literacy. Learned publishing, 15(4), p. 297-301.

2. Bell, D. (1987). The Post-industrial society: A conceptual schema. Evolution of an information Society. Ed. A. E. Cawkell. London: Aslib.

3. Beyer, Barry K. (1995). Critical Thinking, Bloomington, Phi Delta Kappa Educational Foundation, p. 33.

4. Brainy Quotes retrieved on 23.02.2017 from https://www.brainyquote.com/quotes/keywords/ information_age.html

5. Brouwer, P.S. (1997). Critical thinking in the information age. Journal of Educational technology systems, 25(2), p. 189-197.

6. Castells, Manuel (2000). The information age: Economy, society and culture, The rise of the network society. Malden: Blackwell, Vol. I: p. 594.

7. Dewey, J. (1933). How We Think. A restatement of the relation of reflective thinking to the educative process (Revised edn.), Boston: D. C. Heath. Brilliant.

8. Ennis, R. H. (2001). Critical thinking assessment. Theory into practice, 32 (3), 179-186.

9. Facione, Peter A (2011), Think Critically, Pearson Education: Englewood Cliffs, NJ.

10. Foundadtion of Critical thinking. Accessed at ttp://www.criticalthinking.org/concepts_tools.pdf.

11. Glaser, E.M. (1985). Critical Thinking: Education for responsible citizenship in a democracy. National Forum, 65, 24-27.

12. Paul, R. (1996). Critical Thinking: What every person needs to survive in rapidly changing world. Santa Rosa CA: Foundation for Critical Thinking.

13. Paul, R., Elder, L. (2006). The Miniature Guide to Critical Thinking: Concepts \& Tools.

14. The value of critical thinking retrieved on 20.01 .2017 from http://www.telacommunications.com /nutshell/cthinking6.htm

15. Toffler, A. (1970). Future Shock, New York: Random House.

16. Vezzosi, Monica (2004). Critical thinking and reflective practice: The role of information literacy, Parma: University of Northumbria, Newcastle. 